\title{
Effects of Aerial Exposure on Antioxidant Defenses in the Brown Mussel Perna perna
}

\author{
Eduardo Alves de Almeida and Afonso Celso Dias Bainy*
}

Laboratório de Biomarcadores de Contaminação Aquática e Imunoquímica; Departamento de Bioquímica; Centro de Ciências Biológicas; Universidade Federal de Santa Catarina; 88040-900; bainy@mbox1.ufsc.br; Florianópolis - SC - Brasil

\begin{abstract}
Investigations were carried out to evaluate the antioxidant defenses in digestive gland of mussels Perna perna held in air for 4 hours, exposed to air for 4 hours followed by submersion in water for 30 minutes, and constantly submerged for 4.5 hours. No differences were observed in CAT and GPX activities and in the levels of total GSH. Mussels exposed to air had significantly higher SOD activity, possibly related to a preparative mechanism of defense against oxidative stress during reoxygenation.
\end{abstract}

Key words: Antioxidant, hypoxia, mussel, Perna perna, aerial exposure

\section{INTRODUCTION}

The intertidal zone is a rigorous environment for sessile animal life. To survive in this environment, animals must be able to endure periodic changes in oxygen and water availability, salinity, and temperature (Storey and Churchill, 1995). Oxygen limitation can arise in several ways including valve closure at low tide, burrowing into oxygendepleted substrate or, especially for mussels, exposure to difficult environmental conditions that reduce seawater oxygen levels or stimulate prolonged periods of valve closure (e.g. high salt levels, toxin and pollutants, predator attack; Greenway and Storey, 1999). Under anoxic conditions, ATP is degraded to AMP and subsequently to hypoxanthine. Upon reoxygenation, hypoxanthine and xanthine are oxidized generating reactive oxygen species (ROS; Jones, 1986). Toxic effects caused by ROS are many and varied, including lipid peroxidation, nucleic acid damage, protein degradation and enzyme inactivation (Winston et al., 1990).

The extent of biological damage caused by ROS is ameliorated by specific antioxidant enzymes, such as catalase (CAT), superoxide dismutase (SOD), and glutathione peroxidase (GPx), which uses the tripeptide glutathione (GSH) as an electron donor to reduce peroxides (Hebbel, 1986; Sies, 1993).

There is little information about the response of such antioxidant defense systems in the brown mussel Perna perna to air exposure. In this work, we analyzed the activity of the antioxidant enzymes SOD, CAT and GPx, as well as the levels of total GSH in digestive glands of mussels $P$. perna exposed to air during 4 hours, exposed to air for 4 hours then re-submersed for $30 \mathrm{~min}$ and in a control group, which was kept constantly immersed in seawater during whole experiment period.

\footnotetext{
* Author for correspondence
} 


\section{MATERIAL AND METHODS}

Mussels $P$. perna of similar length $(6-7 \mathrm{~cm})$ were collected in July 1997 at Joaquina beach (Florianópolis, SC, Brazil) and separated into three groups of eight organisms that were simultaneously exposed to different conditions. At the same site, Group 1 was kept immersed in seawater for 4.5 hours. Group 2 was exposed to air for 4 hours and Group 3 was exposed to air for 4 hours and re-submerged in seawater for 30 minutes. Water temperature during the experiment was $16^{\circ} \mathrm{C}$.

After this treatment, the mussels were killed and their digestive gland were excised and frozen in liquid nitrogen. The tissues were weighed and homogenized with $5 \mathrm{ml} / \mathrm{g}$ of buffer (Tris $\mathrm{HCl} 50$ $\mathrm{mM}, 0.15 \mathrm{M} \mathrm{KCl}, \mathrm{pH} 7.4$ ), and centrifuged at $10,000 \mathrm{~g}$ for $20 \mathrm{~min}$ at $4^{\circ} \mathrm{C}$. The supernatant fraction was centrifuged at $40,000 \mathrm{~g}$ for $60 \mathrm{~min}$ at $4^{\circ} \mathrm{C}$. The supernatant was used to analyze the activity of SOD, CAT and GPx.

SOD activity was evaluated by the inhibition of reduction of cytochrome $c$ in the presence of hypoxanthine/xanthine oxidase $\mathrm{O}_{2}^{-\cdot}$ generating system at 550nm (McCord and Fridovich, 1969). One unit of SOD is defined as the amount of enzyme that promotes a $50 \%$ inhibition of the cytochrome $c$ reduction at $\mathrm{pH} 7.8$ and $25^{\circ} \mathrm{C}$. CAT activity was quantified at $240 \mathrm{~nm}$ by the $\mathrm{H}_{2} \mathrm{O}_{2}$ decomposition according to the method of Beutler (1975). GPx activity was assayed by the oxidation of NADPH (linked to GSSG reduction by excess glutathione reductase) at $340 \mathrm{~nm}$, according to Sies et al. (1979). The total protein content was determined by method of modified Lowry, using bovine albumin as standard (Peterson, 1977).

Pieces of digestive gland were homogenized in 10 $\mathrm{ml} / \mathrm{g}$ perchloric acid $0.5 \mathrm{M}$ and centrifuged for 2 $\min$ at $15,500 \mathrm{~g}$ at room temperature. After centrifugation, the supernatant fraction was neutralized with $\mathrm{K}_{3} \mathrm{PO}_{4}$ and total GSH was determined in this fraction by continuous reduction of 5,5'-dithiobis, 2-nitrobenzoic acid (DTNB) in the presence of oxized glutathione (GSSG), glutathione reductase (GR) and NADPH, at $412 \mathrm{~nm}$ according to method described by Tietze (1969).

Data were statistically compared using One-Way Analysis of Variance, followed by Student Newman-Keuls test, using the software Statistica for Windows (Zar, 1984).

\section{RESULTS AND DISCUSSION}

Mussels experience changes in the levels of available oxygen associated with tidal cycle. Complex biochemical and physiological mechanisms enable this organism to survive under these extreme conditions and to recover from hypoxia resulting from exposure at low tide (de Zwaan and Wijsman, 1976; Shick et al., 1986; Zange et al., 1989). On the other hand, behavioral mechanisms, such as shell gapping, may also enhance survival at low tides, where small shell movements can assist both in the maintenance of aerobic metabolism (Kennedy, 1976; Widdows et al., 1979; Guderley et al., 1994) and the removal of anaerobic waste products (Demers and Guderley, 1994).

One strategy commonly used by intertidal bivalves during tidal exposure is a reduction in oxygen consumption. Some bivalves, including Mytilus edulis, Mytilus galloprovincialis (Widdows et al., 1979), Choromytilus meridionalis (Griffiths and Buffestein, 1981) and Perna canaliculus (Marsden and Weatherhead, 1998) show reductions of up to $80 \%$ in their oxygen uptake under these conditions. Willson and Burnett (2000) observed that the oxygen uptake of the oyster Crassostrea virginica exposed to air was less than $0.1 \%$ of their oxygen uptake in well-aerated seawater. We could also expect a concomitant reduction in antioxidant enzymes of the mussels, since the production of ROS would probably be reduced during periods of low tissue oxygenation.

However, in the present study, we observed that the activity of the antioxidant enzymes CAT and GPx as well as the levels of total GSH of the three different groups of mussels were similar (Figure1), even when mussels were exposed to air for 4 hours. Conversely, mussels exposed to air exhibited higher SOD activity.

Hermes-Lima et al. (1998) observed an increase in the antioxidant defenses during land snail estivation, suggesting that this response was a preparative mechanism against oxidative stress during arousal. Thus, a wide range of stress tolerant animals would display coordinated changes in antioxidant defenses that allow them to deal with oxidative stress that occurs as part of natural cycles of stress/recovery that alter oxygen levels in tissues. 

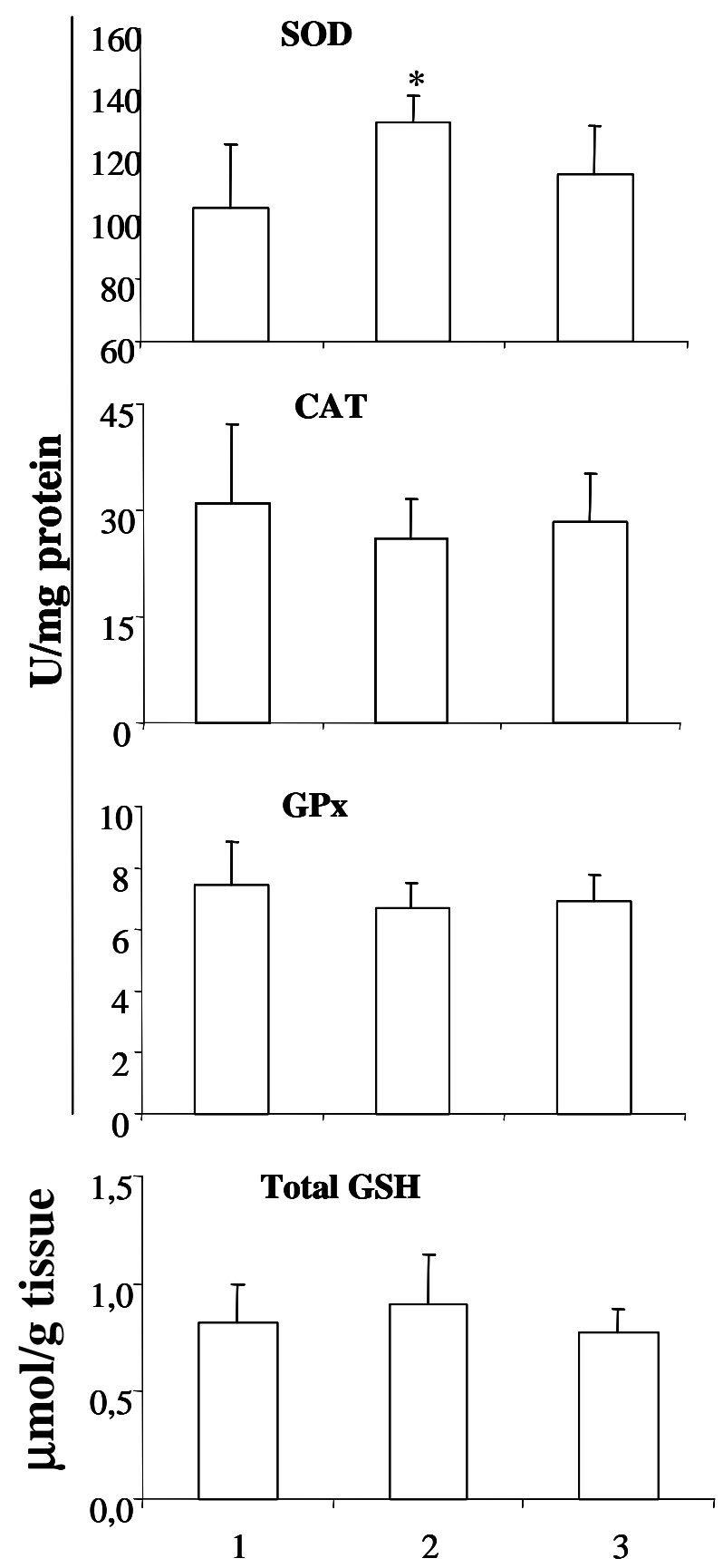

Figure 1 - Activities of SOD, CAT, GPx, and levels of Total GSH in digestive gland of mussels submersed in seawater for 4.5 hours (1), exposed to air for 4 hours (2), and exposed to air for 4 hours followed by re-submersion in seawater for 30 minutes. *indicates statistical differences $(\mathrm{p}<0.05)$ between group 1 and $2 . \mathrm{N}=7$ for groups 1 and 3 , and $\mathrm{n}=8$ for group 2 .

Moreover, it has been shown that in several euryoxic bivalve molluscs there is only xanthine dehydrogenase and no xanthine oxidase activity (Dykens and Shick, 1988; Cancio and Cajaraville, 1997; Cancio and Cajaraville, 1999). This was interpreted as a mechanism to avoid the harmful effects of ROS that would be produced by xanthine oxidase during periods following anoxic conditions at low tides. Xanthine dehydrogenase can also produce superoxide anion radical, although only $10-25 \%$ of the amount that xanthine oxidase produces (Kooij et al., 1994; Sanders et al., 1997). 
The increase in antioxidant defense enzymes seen in our study could thus be an adaptation to the high levels of ROS that are produced during the submersion period of the tidal cycle. However, the molecular mechanisms that trigger and regulate changes in antioxidant enzyme activities are still unknown and remain to be clarified.

\section{ACKNOWLEDGEMENTS}

We would like to thank Bruce R. Woodin for revising this manuscript. This work was supported by the National Council for Scientific and Technologic Development, Ministry of Science and Technology, Brazilian Government (CNPq; No.420062/97-1) and Funpesquisa-UFSC. A.C.D.B. is recipient of productivity fellowship from CNPq.

\section{RESUMO}

Mexilhões são periodicamente submetidos a condições de hipóxia seguido de normóxia, como resultado das oscilações nos níveis de maré. Tais condições podem causar um aumento na produção de espécies reativas de oxigenio (EROs) nos tecidos, devido a um aumento no fluxo de oxigênio e de equivalentes redutores. Para proteger as células contra as EROs, os organismos possuem enzimas antioxidantes tais como a superóxido dismutase (SOD), catalase (CAT) e glutationa peroxidase (GPx), assim como o tripeptídeo glutationa (GSH). Neste trabalho, estas defesas antioxidantes foram avaliadas em glândulas digestivas de mexilhões Perna perna expostos ao ar por 4 horas seguido de re-submersão em água do mar por 30 minutos e constantemente submersos por 4,5 horas. Nenhuma diferença foi observada nas atividades da CAT e GPx, assim como nos níveis de GSH total. Mexilhões expostos ao ar tiveram atividade da SOD significativamente maior, possivelmente relacionado a um mecanismo de defesa preparativo contra o estresse oxidativo durante a reoxigenação.

\section{REFERENCES}

Beutler, E. (1975), Red Cell Metabolism: A manual of biochemical methods. New York: Grune and Straton 342 pp.

Cancio, I. and Cajaraville, M. (1997), Histochemistry of oxidases in several tissues of bivalve molluscs. Cell Bio. Inter., 21, 574-584.

Cancio, I. and Cajaraville, M. (1999), Seasonal variation of xanthine oxidoreductase activity in the digestive gland cells of the mussel Mytilus galloprovincialis: A biochemical, histochemical and immunochemical study. Bio. Cell, 91, 605-615.

Demers, A. and Guderley, H. (1994), Acclimatization to intertidal conditions modifies the physiological response to prolonged air exposure in Mytilus edulis. Mar. Biol., 118, 115-122.

de Zwaan, A. and Wijsman, T. C. M. (1976), Anaerobic metabolism in Bivalvia (Mollusca). Characteristics of anaerobic metabolism. Comp. Biochem. Physiol., 54(B), 313-324.

Dykens, J. A. and Shick, J. M. (1988), Relevance of purine catabolism to hypoxia and recovery in euryoxic and stenoxic marine invertebrates, particulary bivalve molluscs. Comp. Biochem. Physiol., 91(C), 35-41.

Greenway, S. C. and Storey, K. B. (1999), The effect of prolonged anoxia on the enzyme activities in oysters (Crassostrea virginica) at different seasons. J. Exp. Mar. Biol. Ecol., 242, 259-272.

Griffiths, R. J. and Buffestein, R. (1981), Aerial exposure and energy input in the bivalve Choromytilus meridionalis (Kr.). J. Mar. Biol. Ecol., 52, 219-229.

Guderley, H.; Demers, A. and Couture, P. (1994), Acclimatization of blue mussel (Mytilus edulis Linnaeus, 1758) to intertidal conditions: effects on mortality and gaping during air exposure. J. Shellfish Res., 13, 379-385.

Hebbel, R. P. (1986), Erythrocyte antioxidants and membrane vulnerability. J. Lab. Clinic Med., 107, 401-404.

Hermes-Lima, M.; Storey, J. M. and Storey, K. B. (1998), Antioxidant defences and metabolic depression. The hypothesis of preparation for oxidative stress in land snail. Comp. Biochem. Physiol., 120(B), 437-448.

Jones, D. P. (1986), Renal metabolism during normoxia, hypoxia, and ischemic injury. An. Rev. Physiol., 48, 33-50.

Kennedy, V. S. (1976), Desiccation, higher temperatures and upper intertidal limits of three species of sea mussels (Mollusca: Bivalvia) in New Zealand. Mar. Biol., 35, 127-137. 
Kooij, A.; Schiller, H. J.; Schijns, M.; Van Noorden, C. J. F. and Fredericks, W. M. (1994), Conversion of xanthine dehydrogenase into xanthine oxidase in rat liver and plasma at the onset of reperfusion after ischemia. Hepatology, 19, 1488-1493.

Marsden, I. D. and Weatherhead, M. A (1998), Effects of aerial exposure on oxygen consumption by the New Zealand mussel Perna canaliculus (Gmelin, 1791) from an intertidal habitat. J. Exp. Mar. Biol. Ecol., 230, 15-29.

McCord, J. M. and Fridovich, I. (1969), Superoxide dismutase: an enzymatic function for erythrocuprein (haemocuprein). J. Biol. Chem., 244, 6049-6055.

Peterson, G. L. (1977), A simplification of the protein assay method of Lowry et al., which is more generally applicable. Anal. Biochem., 83, 346-356.

Sanders, S. A.; Eisenthal, R. and Harrison, R. (1997), $\mathrm{NADH}$ oxidase activity of human xanthine oxidoreductase-generation of superoxide anion. European J. Biochem., 245, 541-548.

Schick, J. M.; Gnaiger, E.; Widdows, J.; Bayne, B. L. and de Zwaan, A. (1986), Activity and metabolism in the mussel Mytilus edulis L. during intertidal hypoxia and aerobic recovery. Physiol. Zool., 59, 627-642.

Sies, H.; Koch, O. R.; Martino, E. and Boveris, A. (1979), Increased biliary glutathione disulfide release in chronically ethanol treated rats. FEBS Let., 103, 287-290.

Sies, H. (1993), Strategies of antioxidant defenses. European J. Biochem., 215, 213-219.

Storey, B. S. and Churchill, T. A. (1995), Metabolic responses to anoxia and freezing by the freeze tolerant marine mussel Geukensia demissus. J. Exp. Mar. Biol. Ecol., 188, 99-114.
Tietze, F. (1969), Enzymic method for quantitative determination of nanogram amounts of total and oxidized glutathione: Applications to mammalian blood and other tissues. Anal. Biochem., 27, 502-522.

Widdows, J.; Bayne, B. L.; Livingstone, D. R.; Newell, R. I. E. and Donkin, P. (1979), Physiological and biochemical responses of bivalve molluscs to exposure to air. Comp. Biochem. Physiol., 62(A), 301-308.

Willson, L. L. and Burnett, L. E. (2000), Whole animal and gill tissue oxygen uptake in the Eastern oyster, Crassostrea virginica: Effects of hypoxia, hypercapnia, air exposure, and infection with the protozoan parasite Perkinsus marinus. J. Exp. Mar. Biol. Ecol., 246, 233-240.

Winston, G. W.; Livingstone, D. R. and Lips, F. (1990), Oxygen reduction metabolism by the digestive gland of the common marine mussel, Mytilus edulis L. J. Exp. Zool., 255, 296-308.

Zange, J.; Portner, O. and Grieshaber, M. K. (1989), The anaerobic energy metabolism in the anterior byssus retractor muscle of Mytilus edulis during contraction and cath. Comp. Biochem. Physiol., 159(B), 349-359.

Zar, J. H. (1984), Biostatistical Analysis. Englewood Cliffs: Prentice-Hall. 718 pp.

Received: May 11, 2004; Revised: September 14, 2004; Accepted: October 11, 2005. 